\title{
Køn, nation, \\ sikkerhed og \\ massevoldtægterne \\ i Bosnien
}

\section{Af Lene Hansen}

Voldtagter var et vasentligt led $i$ krigsforelsen $i$ Bosnien, ikke mindst fordi de rettede sig mod baide den nationale og den konslige identitet. I kølvandet fulgte en fortolkningsmassig og politisk debat om Vestens sikkerbedspolitiske ansvar.

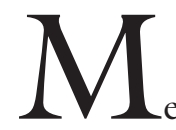

ed krigen i Bosnien kom køn på den internationale sikkerhedsdagsorden i et hidtil uset omfang. Fra Roy Gutman's første afsløringer af overgreb i august 1992 og det næste halvandet år frem var massevoldtæger et fremtrædende tema i den vestlige mediedækning af Bosnien (Stanley 1999). Denne opmærksomhed var, set i et historisk lys, bemærkelsesværdig og overraskende: gennem historien er der utallige eksempler på, at voldtægt er blevet accepteret som den sejrrige soldats belønning og som et middel til at ødelægge den besejrede befolknings sociale netværk (Brownmiller 1975, 31-40). Den succesfulde voldtxgt ydmyger både kvinder og mænd; kvinder ses af sig selv og muligvis også af deres omgivelser som beskidte, og mænd feminiseres gennem deres manglende evne til at have ydet "deres kvinder" beskyttelse.

Mediernes, politikernes og Den Internationale Domstol for det tidligere Jugoslaviens opmærksomhed på massevoldtægt var 
imidlertid ikke udtryk for en simpel enighed om, at kvinder skal etableres som et væsentligt subjekt i international sikkerhedspolitik. Behandlingen af de bosniske massevoldtæger illustrerer derimod, hvorledes forskellige læsninger af voldtægternes betydning konkurrerede med og komplimenterede hinanden. Mere præcist kan man identificere diskursive kampe om, hvorvidt voldtægterne skal ses indenfor en national eller en kønsmæssig optik, og om voldtægt skal ses som et individuelt eller et kollektivt fænomen. Til disse forskellige representationer af voldtægternes karakter og betydning var koblet konkurrerende politikker: skulle voldtægterne modsvares af vestlig militær intervention, skulle der interveneres i forhold til de krænkede kvinder eller skulle Vesten afholde sig fra at gribe ind? Det er denne artikels formål at analysere dynamikken i disse repræsentationer af massevoldtægterne; at vise hvorledes de forsøger at stabilisere bestemte subjektkonstitueringer og sikkerhedsforståelser frem for andre, samt vise hvorledes de giver anledning til bestemte politikanbefalinger.

Første del af artiklen vil dels give en indføring i sikkerhedsbegrebets udvikling og hvordan kønsrelaterede sikkerhedsproblemer kan indtænkes teoretisk i en større ramme, dels introducere en forståelse af voldtxgt som et både kollektivt og individuelt fænomen. Den anden del af artiklen vil anvende disse teoretiske betragtninger $\mathrm{i}$ en analyse af de tre kerne-repræsentationer, som satte sig igennem i den vestlige debat om de bosniske voldtæger. Den første repræsentation, "Voldtægt som normal/ balkansk krigsførelse", konstituerer voldtrgt som et individuelt problem og en naturlig del af krigsførelse. Der er med andre ord ikke tale om et kollektivt sikkerhedsproblem, og derfor heller ikke noget krav, om at voldtxgterne skal imødegås af det internationale samfund. Den anden repræsentation, "Voldtægt som exceptionel/serbisk krigsførelse", artikulerer voldtægt som et nationalt sikkerhedsproblem rettet mod den bosniske stat og nation. Vesten har inden for denne repræsentation det politiske ansvar for en intervention, som vil stoppe voldtægterne og imødegå faren for en fremtidig gentagelse. Den tredje og sidste repræsentation, "Det balkanske patriarkat", skifter fokus fra en national til en kønsbaseret optik. Her ses alle kvinder uanset deres nationale og religiøse tilhørsforhold som potentielt truede af en patriarkalsk kultur, mens den politiske handlingsanvisning er noget mere tvetydige end $\mathrm{i}$ de første to repræsentationer.

\section{SIKKERHEDSDEBATTENS DIKOTOMIER}

I de seneste 15 år har man inden for disciplinen sikkerhedsstudier debatteret kraftigt om sikkerhedsbegrebets traditionelle såkaldte realistiske fokus på statens militære sikkerhed skulle udvides (Krause and Williams 1996, 229-30, Buzan 1998). Argumenterne for en udvidelse har været, at en lang række ikke-militære trusler er lige så væsentlige for sikkerheden som de rent militære, og at staten ikke nødvendigvis beskytter befolkningens sikkerhed, men snarere kan true den (Booth 1991). En priviligering af et statsligt-militært sikkerhedsbegreb indebærer samtidig en bestemt politisk og normativ afgrænsning, som betyder, at andre potentielle ikke-militære, ikke-statslige problemer ikke kommer på dagsordnen (Booth 1991, 1997). Modargumentet fra den statslig-militære tilgang har været, at hvis sikkerhedsbegrebet udstrækkes til at omfatte alle områder og aktører fra individet til det globale, så mister begrebet sin analytiske og politiske relevans. Hvis alt er sikkerhedsproblemer, er der ikke nogen mulighed for at adskille "virkelige", truende sikkerhedsproblemer fra mindre presserende spørgsmål.

Fra feministisk hold har man ikke overraskende placeret sig på "udvidelsessiden" af denne debat og påpeget, at et statsligmilitært sikkerhedsbegreb giver begrænsede, om nogen, muligheder for at identifi- 
cere kønsrelaterede sikkerhedsproblemer. Som Jill Sterns har formuleret det:

A feminist analysis of the military and the patriarchal state raises questions about the validity of continuing to view the state as the mainstay of security and of assuming that security for the individual is adequately understood in terms of her or his membership of a given national community. (Steans 1998, 104, min kursivering LH; se også Tickner 1992, 54-66, Grant 1992).

Modstillingen mellem individets sikkerhed og nationens/statens sikkerhed baserer sig ud fra en feministisk og sikkerhedsteoretisk optik således på to dikotomier: en som konstituerer individet i modsætning til kollektivet, og en som konstituerer nationen i modsætning til det kønsbaserede fællesskab. I stedet for at se sikkerhedsbegrebet som et valg mellem individ eller kollektiv, og mellem nation og køn, er det mere frugtbart at se sikkerhedsdebatter som udspundet i spændingen mellem de to dikotomier. Enhver representation af et sikkerhedsproblem vil indebære en bestemt konstituering af individuelle og kollektive hensyn: et individuelt sikkerhedsproblem kan ikke sætte sig igennem på den politiske arena uden samtidig at have en række kollektive implikationer. Tilsvarende er det yderst vanskeligt at formulere kønsbaserede sikkerhedsproblemer uden at indtænke statens betydning, da den suveræne territorialstat har været den dominerende politiske organisationsform i mere end 400 år (Walker 1992, Hansen 2000b). "Kvinders sikkerhed" kan derfor hverken formuleres eller studeres uden at inddrage staten og nationens betydning, og det må derfor være et af den feministiske forsknings formål at vise og dekonstruere, hvorledes den statslige optik sætter begrænsninger for en kønsbaseret forståelse af sikkerhed.

\section{FORSTÅELSEN AF MASSEVOLDTÆGTER}

Selvom feminister, med Susan Brownmiller som foregangskvinde, har peget på voldtægt som en trussel mod kvinders liv i snart 30 år, er det først for nyligt, at man fra bredere politisk og forskningsmæssigt hold er begyndt at se på voldtægt som et muligt sikkerhedsproblem (Brownmiller 1975, MacKinnon 1989, 171-183). Denne anerkendelse er fokuseret på krigsvoldtægter som en trussel mod nationens sikkerhed, og der ligger dermed implicit en adskillelse mellem krigsvoldtægter og massevoldtægter på den ene side, og "normale" voldtæegter som foregår i fredstid, og som dermed ikke anerkendes som et sikkerhedsproblem på den anden side. Konstruktionen af "fredstidsvoldtxgter" som et individuelt anliggende indebærer, at den enkelte kvinde pålægges et ansvar for at opføre sig "fornuftigt", dvs. ikke at optræde seksuelt udfordrende, undgå øde steder, og ikke tage fremmede mænd med hjem. Denne konstruktion ser voldtægten i seksuelle termer og ofrets seksuelle historie vil derfor i mange tilfælde være relevant materiale i en retssag. "Krigsvoldtægter" bliver på den anden side konstrueret som et kollektivt sikkerhedsproblem. Voldtægt ses ikke som relateret til et spørgsmål om kvindens seksuelt udfordrende handling, men som et spørgsmål om national, religiøs og etnisk identitet og krigsførelse. Handlingen afseksualiseres og kvindens ansvar og forhistorie opløses i den nationale ramme.

Når voldtægt i krig tidligere er blevet set som "normal adfærd", som ikke fortjente en særlig opmærksomhed og udpegning som et sikkerhedsproblem, hænger det sammen med, at soldaterne ses som placeret uden for den normale offentlige sfære, hvor de ville blive holdt ansvarlige for deres handlinger. Der var også en stiltiende accept af, at den mandlige seksualdrift, måske yderligere opildnet af slagmarkens kampe, krævede en tilfredsstillelse. Accepten af krigsvoldtægter som et sikkerhedsproblem underminerer legitimiteten af denne mand- 
lige figur, men lægger stadig afgørende vægt på, om en voldtægt er foregået inden for rammerne af en militær operation eller ej, og om den er udført at en soldat, som handler i sin militære kapacitet. Spørgsmålet bliver så, hvorledes den private/militære kapacitet defineres? Kan en soldat handle i privat kapacitet, når han er i krig eller er han konstant, selv når han ikke er på vagt, at betragte som handlende i officielt regi?

Hvis vi betragter spørgsmålet om voldtægt i lyset af dikotomien mellem det individuelle og det kollektive, som blev præsenteret ovenfor, så kan man formulere det sådan, at en voldtrgt altid udføres mod et individ, men at denne handling indskrives og gives betydning inden for en kollektiv ramme - også hvis denne indskrivning ser kvindens voldtrgt som et produkt af acceptabel soldateradfærd eller hendes egen risikofyldte adfærd. I de tilfælde er selve de normer, som regulerer "acceptable soldateradfærd" og "risikofyldt adfærd" et udtryk for en bestemt kollektiv definering af det acceptable og det grænseoverskridende.

Dikotomien mellem den nationale og den kønsdefinerede konstruktion af et sikkerhedsproblem er også central for forståelsen af krigsvoldtægter. Voldtægterne bliver i denne optik en praksis, som konstituerer og indskriver national og kønsbaseret identitet. (Butler 1990, 33) Mere specifikt har massevoldtægterne i Bosnien adskilt "kvinder" fra "mænd" og "Bosniere" fra "Serbere", samtidig med at de har sigtet mod at tilskrive disse over- og underordnede kønsmæssige og nationale identiteter (Stiglmayer 1994, 85; Ramet, 1996: 284). Voldtxgterne konstituerer de to nationale grupper med bestemte kønsmæssige identiteter: når "nationens kvinder" voldtages er der ikke blot tale om vold mod individuelle kvinder, men om en underminering af nationens mænds maskulinitet. På den ene side kan man derfor se massevoldtægterne som "nationens destruktion" (Nikolic-Ristanovic 1996, 202, Allen 1996, 97), men på den anden side kan man også sige, at de indskriver den nationalitetsfølelse, de forsøger at udslette, da den voldtagne part drives mod en identifikation af sig selv som for eksempel bosnier.

\section{REALISMENS SIKKERHEDSFORSTÅELSE: "VOLD-TÆGT SOM NORMAL/BALKANSK KRIGSFØRELSE”}

Den første repræsentation af voldtægterne er placeret inden for den realistiske statslige og militære sikkerhedsoptik, som blev præsenteret ovenfor. Inden for denne diskurs finder intervention kun sted, hvis der er tale om trusler mod den nationale interesse. I den bosniske situation betød det, at Vesten kun skulle intervenere, hvis der var tale om trusler mod europæiske sikkerhedsinteresser - trusler mod bosniske kvinder ville med andre ord ikke være nok til at udløse en vestlig reaktion. Denne repræsentation koblede den generelle afvisning af voldtægt som et særligt sikkerhedsproblem til en mere specifik repræsentation af krigen i Bosnien som et "balkansk fænomen". "Balkan" var radikalt forskellig fra Europa og Vesten og havde, blev det anført, en lang tradition for etnisk had, vold og brutalitet, hvilket bevirkede at vestlig intervention ville være yderst vanskelig og til syvende og sidst ude af stand til grundlæggende at løse konflikten (Hansen 2000a, Todorova 1997). Som George F. Kennan skrev om de første Balkan krige i 1912 og 1913: "Woe betided the man of military age, or the woman of 'enemy' national identity, who were found alive in the conquered village. Rape was ubiquitous, sometimes murderous." (Kennan 1993, 10). Når massevoldtægterne blev læst gennem denne linse af "balkansk brutalitet" kunne det fremføre, at ekstrem voldelighed altid havde fundet sted på Balkan, og at selvom serberne havde udført flere voldtægter end bosnierne, så var ingen af parterne uskyldige. Repræsentationen af "Balkan" som ikke-vestlig og voldtrgt som et "normalt" aspekt ved krigsførelse blev dermed et dobbelt ar- 
gument til forsvar for, at Vesten ikke skulle intervenere $i$ Bosnien. Privilegeringen af den nationale sikkerhed, og forskellen mellem "Vesten" og "Balkan" distancerede Vesten fra krigen såvel etisk som politisk.

Men hvis vi ser mere kritisk - eller dekonstruktivistisk - på, hvorledes diskursen forsøger at stabilisere denne repræsentation af balkanske og vestlige subjekter og koblingen til (en fraværende) intervention gennem etablering af entydige identiteter med klare grænser, så finder vi, at diskursen ikke er fuldstændig stabil eller uden indre modsætninger. Vægten på “Balkans” identitet og historie i representationen sættes overfor den implicitte konstituering af voldtægt som en handling med kønsmæssige implikationer. Diskursen deler dermed det politiske felt op mellem "mænd" og "kvinder", og dermed er "Balkan" altså ikke blot en fuldstændig udifferentieret "voldelig" masse, men består af "truende mænd" og "sårbare kvinder". Skulle Vesten så ikke påtage sig ansvaret for disse kvinders forsvar? Dette spørgsmål peger på en intern konflikt i "voldtrgt som normal/Balkansk krigsførelse" repræsentationen: det er denne repræsentations fortrukne position at konstituere Vesten og Balkan som radikalt forskellige, men inddragelsen af et kønsmæssigt aspekt via massevoldtægterne underminerer en simpel læsning af "Balkan" ved at pege på forfølgelsen af kvinder. Den vestlige afvisning af intervention og handling kan derfor kun finde sted via en afvisning af en etisk ansvarlighed for andres sikkerhedsproblemer. Dette betyder, at selvom repræsentationen lægger eksplicit vægt på en konstruktion af sikkerhed i nationale termer, så leder inddragelsen af kønsmassige spørgsmål til en destabilisering af representationen.

NATIONENS SIKKERHED:

"VOLDTÆGT SOM EXCEPTIONEL/SERBISK KRIGSFØRELSE"

Som hos den realistiske representation ta- ges der også her udgangspunkt i en sikkerhedsforståelse, som privilegerer det nationale, men der argumenteres i modsætning til realisterne for, at internationale interventioner ikke kun skal baseres på snævre nationale interesser. Nationer, som er udsat for aggressioner og som er ofre for etnisk udrensning og folkemord, bør forsvares af det internationale samfund desuagtet de potentielle regionale konsekvenser. I denne optik blev krigen i Bosnien ikke set som en "Balkansk borgerkrig", men som en aggression fra Serbien/Jugoslaviens side mod den suveræne stat Bosnien, og i modsætning til en læsning af krigen som baseret på "århundrede år gammelt etnisk had" som den realistisk representation argumenterede for, sås den som et udtryk for en bevidst serbisk kampagne, hvor massevoldtægterne udgjorde en central del (Cohen 1996, 53 og 47)

Ikke overraskende var det denne repræsentation, som den bosniske regering placerede sig inden for $\mathrm{i}$ et forsøg på mobilisere en mere markant vestlig støtte til den bosniske regeringshærs side. I et tale til FN's Sikkerhedsråd den 24 august, 1993 sagde den bosniske ambassadør Muhamed Sacirbey at: "Bosnia and Herzegovina is being gang raped. ...... I do not lightly apply the analogy of a gang rape to the plight of the Republic of Bosnia and Herzegovina. As we know, systematic rape has been one of the weapons of this aggression against the Bosnian women in particular" (citat fra Mestrovic 1994, xii) Også fra vestlig og bosnisk feministisk side fik denne repræsentation støtte og det blev fremført, at voldtægterne var et forsøg på folkemord og "unique in the history of rapes and many of them demand military intervention to rescue the women." (Stiglmayer 1994, 162).

Konstruktionen af massevoldtægterne som et unikt historisk fænomen bliver koblet til en representation af homogene nationale serbiske og bosniske grupper, hvor den serbiske nationalisme udpeges som radikalt forskellige fra den vestlige og den 
centraleuropæiske. Beverly Allen hævder i den nok mest citerede bog om voldtxgterne, at den 'advocate[s] vengeance', and 'derive[s] from the blood-cloudy mists of extremist Serb nationalist legend' of which the most important element is 'the Chetnik cult of the knife'" (Allen 1996, 16, 42, 7981). Den serbiske strategi med at bruge voldtægter til at gøre bosnisk muslimske kvinder gravide, og dermed få dem til at "føde en serber", udgjorde ifølge Allen ligeledes en nyskabelse i krigsføringens historie, som ikke engang nazismen betjente sig af (Allen 1996, 91). Voldtægter er også blevet begået af bosniske styrker, men der har her kun været tale om sporadiske og spontane tilfælde (Cohen 1996, 53).

"Voldtrgt som exceptionel/serbisk krigsførelse" argumenterer for, at krigsvoldtæger udgør et alarmerende sikkerhedsproblem som det internationale samfund må gøre sit yderste for at stoppe. Modstillingen mellem de intentionelle serbiske voldtægter og de spontane bosniske implicerer imidlertid en mere accepterende holdning til "private" voldtægter. Opdelingen i to forskellige former for voldtæegt, de intentionelle som er en del af en militær strategi, og de spontane som (tilsyneladende) ses på baggrund af et mandligt seksuelt behov, betyder, at der inden for denne representation stadig efterlades plads til den traditionelle konstruktion af voldtrgt som et beklageligt, men forventeligt aspekt ved krig.

Den analytiske og dekonstruktivistiske pointe her er ikke at påstå, at serbiske og bosniske styrker udførte voldtxgter i samme omfang, men at påpege at denne repræsentation trækker på en konstruktion af bosnisk national identitet og en traditionel forståelse af krigsvoldtægt, som gør bosniske voldtxgter forskellige fra og mere acceptable end serbiske ved at konstituere en stabilitet omkring modstillingen mellem "spontanitet" og "intention". Fra den enkelte kvindes side kan man imidlertid hævde, at det ikke gør den store forskel om voldtægten ses som spontan eller intentionel. Når den enkelte voldtægt placeres inden for en national sikkerhedsdiskurs sker der imidlertid det, at individets oplevelse underordnes en kollektiv læsning.

Konsekvensen af den kollektive læsning af voldtxgterne som et spørgsmål om national sikkerhed er, at selvom voldtægterne konstitueres som et væsentligt sikkerhedsproblem, så bliver kvindernes interesser og problemer set som identiske med det kollektive "Bosnien". Konkret har det for eksempel betydet en tøvende anerkendelse af de problemer som voldtagne kvinder har mødt i de tilfælde, hvor de er blevet forladt af deres mænd, udelukket af deres samfund, og i nogle tilfælde myrdet (Stiglmayer 1994, 91, Seifert 1994, 59, FolnegovicSmalc 1994, 179). Konstruktionen af voldtægterne som udtryk for særlige former for national krigsførelse betyder, at individuelle voldtæger tillægges forskellige betydninger og værdier afhængig af ofrets nationale tilhørsforhold, og at eventuelle ligheder i kvinders oplevelser på tværs af de krigsførende parter falder uden for optikken.

Det politiske krav fra "voldtægt som exceptionel/serbisk krigsførelse" repræsentationen er en vestligt militær intervention til fordel for den bosniske regering (Mestrovic 1994). I Stiglmayers interviews med bosniske kvinder, som havde været udsat for voldtægt, indtog de fleste den samme holdning og "asked that the world intervene militarily or lift the weapons embargo so that the war, and with it the rapes and expulsions, would cease." (Stiglmayer 1994, 164) Det at "even one person has been subjected to such treatment should be enough to guarantee immediate and effective intervention to stop it" (Allen 1996, 66). Den humanitære intervention, som var iværksat under FN, blev set som utilstrækkelig til at sikre Bosnien og de bosniske kvinders sikkerhed. Efter voldtægterne og krigen ses det som væsentligt, at gerningsmændene forfølges og at der tilbydes støtte og rådgivning til de voldtagne kvinder. 


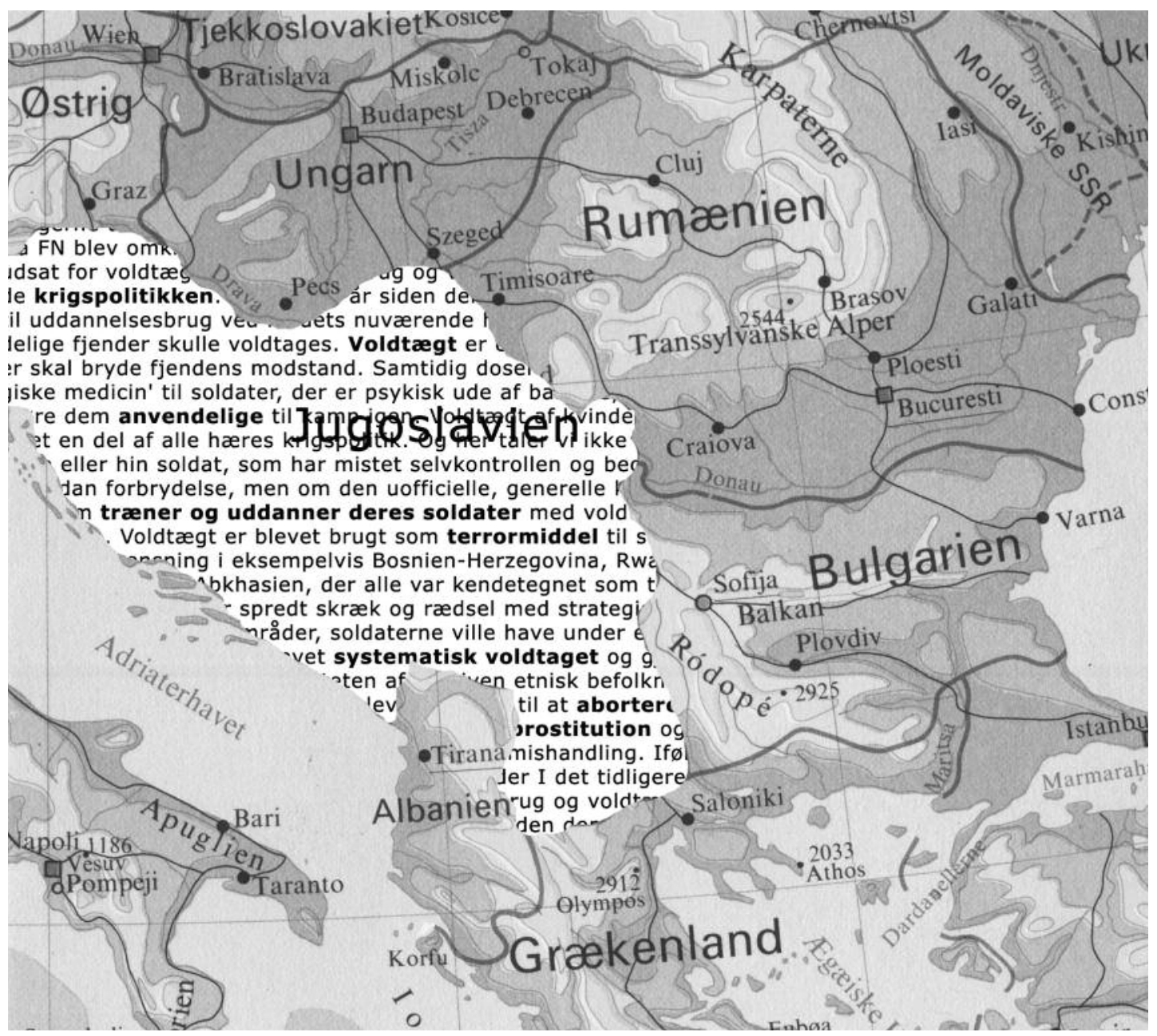

Collage: Nicolai Elver Anton 
FEMINISMENS SIKKERHEDSFORSTÅELSE: "BALKANSK PATRIARKAT"

Udgangspunktet for repræsentationen "Balkansk patriarkat" er den feministiske kritik af den traditionelle accept af voldtægter i krig. Radikale feminister har hævdet, at mænd i krig deler en forståelse på tværs af fronterne af voldtægt, prostitution og pornografi som "an excess of passion in peace or the spoils of victory in war, or as the liberties, civil or otherwise, of their perpetrators." (MacKinnon 1994, 185). "Balkansk patriarkat" representationen er ikke blot yderst kritisk overfor dette (maskuline) syn på voldtægt og krig, den angriber også distinktionerne mellem strategisk og følelsesbetonet voldtrgt og mellem voldtxgt som i nogle tilfælde et international sikkerhedsproblem og $\mathrm{i}$ andre et individuelt problem. I stedet, påpeges det, bør man fokusere på de fællestræk, som kendetegner alle voldtxgter, og dermed udfordre forståelsen af sikkerhed og trusler som knyttet til det nationale fællesskab. Når den nationale ramme erstattes af en kønsbaseret, bliver den bosniske krig set som en kamp mellem patriarkalske og nationalistiske ledere på den ene side og truede kvinder på den anden. Denich skriver at: "Male perpetrators appropriated women simultaneously as objects of sexual violence and as symbols in a contest with rival males that replicated the traditional forms of Balkan patriarchy, in which men's inability to protect 'their' women and to control their sexual and procreative powers is perceived as a critical symptom of weakness." (Denich 1995, 68, min kursivering, LH, Brownmiller 1994, 180, Morokvasic 1998, 68). Mere specifikt pegede Cathrine MacKinnon på, at den udbredte tilstedeværelse af pornografi i Jugoslavien efter kommunismens sammenbrud havde "created a population of men prepared to experience sexual pleasure in torturing and killing women." (MacKinnon 1994, 192).

Hvor "voldtrgt som exceptionel/serbisk krigsførelse" repræsentationen kon- struerede maskulin identitet radikalt forskelligt, når der var tale om henholdsvis Serbien og Bosnien, lægger "balkansk patriarkat” vægt på de identiske maskuline træk, som går på tværs af de nationale grupper. Denne repræsentation muliggør en inklusion af sikkerhedsproblemer, som stammer fra privatsfæren og det "ikke-nationale" for eksempel trusler mod hjemvendte voldtagne kvinder, som oplever modstand i deres egen familie eller samfund, øget vold i hjemmet som følge af krigens stress og oplevelser, samt forekomsten af voldtægter $i$ alle nationale lejre. Svagheden ved denne repræsentation er, at konstruktionen af "patriarkat" generelt og "Balkansk patriarkat" specifikt støtter sig på en ganske stabil, biologisk og essentialistisk forståelse af mænd, som styret af et sæt af drifter (Elshtain 1981, 207-208). "Kvinder" bliver som konsekvens og i modsætning hertil konstrueret som ikke-voldelige og udenfor kamphandlingerne. Dermed nedtones både de kvinder, der i Elshtain's terminologi optræder som Spartanske Mødre, der opfordrer og støtter sønner og mænd i krig og nationalisme (Elshtain 1987, 99-101); ældre kvinders socialisering af yngre kvinder til en accept af patriarkalske strukturer; de kvinder som kxmper i krigen samt mere specifikke fænomener som kvinder og børns blokade af FN køretøjer (Elshtain 1987, 167-171). Men vigtigst er nok alligevel, at denne konstruktion af "mænd" og "kvinder" kommer tæt på en romantisk figur, hvor kvinder ses som essentielt forskellige fra mænd og som nationens omsorgsfulde kerne. Denne privilegerede position er dog betinget af, at kvinder holder sig væk fra strategiske overvejelser og det politiske felt, og rummet for "Balkanske kvinders" politiske handlinger og ansvar bliver dermed begrænset (Elshtain 1981, 204-228). Denne repræsentation løber desuden ind i det problem, at de fleste interviewede voldtagne bosniske kvinder har talt inden for rammerne af en "voldtægt som exceptionel/serbisk krigsførelse" og ikke 
indenfor den feministiske "balkansk patriarkat"-repræsentation. "Løsningen" for sidstnævnte repræsentation bliver så enten at overhøre dette eller at forklare det med de patriarkalske strukturers dominans.

De to første repræsentationers politiske anbefalinger var klare, "voldtægt som normal/Balkansk krigsførelse" afviste vestlig intervention, mens "voldtrgt som exceptionel/Serbisk krigsførelse" krævede militær indgriben til fordel for den bosniske regering. "Balkansk patriarkat" er til sammenligning mere tvetydig og peger i forskellige politiske retninger. Den radikalt truende situation i Bosnien kalder på intervention, men når konflikten læses i kønsmæssige termer kompliceres spørgsmålet om, hvilken form interventionen bør tage. For det første fordi aggressiv mandlig adfærd ses som en følgesvend til al militær handlen, også en eventuel vestlig militær indgriben, som set $\mathrm{i}$ de anklager der er fremkommet mod fredsbevarende styrker for have betjent sig af seksuelle tjenester og prostituerede (MacKinnon 1994, 192). For det andet fordi mange af de feminister, som gjorde opmærksom på massevoldtægterne, havde en baggrund i fredsbevægelsen og dermed en anti-militaristisk indstilling (Stanley 1999, 99). Samlet betyder det, at en fælles Feministisk politik er svær at identificere.

\section{AFSLUTNING - EFTER KRIGEN}

Krigen i Bosnien blev afsluttet i efteråret 1995 efter en massiv NATO-operation skubbede de bosniske serbere tilbage og Dayton-aftalen blev indgået. Hvilken repræsentation kan så siges at have været mest succesfuld? Det er ikke nemt at give et entydigt svar. Skal man se interventionen i 1995 til fordel for den bosniske regeringshær som en bekræftelse af "voldtægt som exceptionel/serbisk krigsførelse"-repræsentationen eller skal man tværtimod se den fraværende intervention fra 1992 til 1995 som udtryk for støtte til en "Voldtægt som
normal/Balkansk krigsførelse" repræsentation? Svaret afhænger i et vist omfang af, hvilket tidsperspektiv som lægges til grund. Som Stanley skriver, havde rapporterne om massevoldtægterne i 1992-1993 lille umiddelbar effekt. På den anden side kan man ikke udelukke, at de på længere sigt hjalp til at opbygge en politisk støtte til en mere massiv vestlig intervention (Stanley 1999, 87).

Efter krigens afslutning er spørgsmålet om massevoldtægterne blev et tema for den internationale krigsforbryderdomstol for det tidligere Jugoslavien. Da domstolen begyndte sit arbejde havde den et forholdsvist begrænset juridisk materiale at bygge på, og flere udtrykte skepsis i forhold til om domstolen ville have kapacitet til og interesse $\mathrm{i}$ at forfølge voldtægternes gerningsmænd (Morokvasic 1998, 82, Copelon 1994, 209-210, Zarkov 1995, 114, Rodgers 1998, 110). Heldigvis må man sige i dag, at domstolen har vist sig villig til at udarbejde voldtægtsrelaterede anklageskrifter og dermed til dels har gjort denne skepsis til skamme. Formodentlig vil det til syvende og sidst blot være et mindre antal voldtægter, som bliver retsforfulgt: bevismaterialet er svært at indsamle og retssagen ofte traumatisk for ofrene, men der er trods alt alligevel grund til at glæde sig over, at Domstolen har gjort en indsats for at få voldtægt betragtet, som et sikkerhedsproblem og en krænkelse, som kan forfølges.

\section{Noter}

1. Denne artikel er en forkortet og lettere bearbejdet udgave af "Gender, Nation, Rape: Bosnia and the construction of security", trykt i International Feminist Journal of Politics, årgang 3, nr. 1, april 2001, side 55-75, hjemmeside: http://www.tandf. co.uk. Jeg takker forlaget for tilladelse til at viderebringe artiklen og Kvinder, Kon og Forsknings referee for værdifulde kommentarer til denne udgave af artiklen. 


\section{LITTERATUR}

- Allen, Beverly (1996): Rape Warfare: The Hidden Genocide in Bosnia-Herzegovina and Croatia. University of Minnesota Press, Minneapolis.

- Booth, Ken (1991): 'Strategy and emancipation', Review of International Studies 17 (4): 313-326.

- (1997): 'Security and Self: Reflections of a Fallen Realist', in Keith Krause and Michael C. Williams (eds.) Critical Security Studies, pp. 83-120. University of Minnesota Press, Minneapolis.

- Brownmiller, Susan (1975): Against Our Will: Men, Women and Rape. Fawcett Columbine, New York.

- (1994): 'Making Female Bodies the Battlefield', in Alexandra Stiglmayer (ed.) Mass Rape: The War against Women in Bosnia-Herzegovina, pp. 180-

182. Lincoln and London: University of Nebraska Press; first published in Newsweek, January 4, 1993, p. 37.

- Butler, Judith (1990): Gender Trouble: Feminism and the Subversion of Identity. Routledge, London. - Buzan, Barry, Ole Wrver, and Jaap de Wilde (1998): Security: A New Framework for Analysis.

Lynne Rienner, Boulder.

. Cohen, Philip J. (1996): 'The Complicity of Serbian Intellectuals in Genocide in the 1990s', in Thomas Cushman and Stjepan G. Mestrovic (eds.) This Time We Knew: Western Responses to Genocide in Bosnia, pp. 39-64. New York University Press, New York.

- Copelon, Rhonda (1994): 'Surfacing Gender: Reconceptualizing Crimes against Women in Time of War', in Alexandra Stiglmayer (ed.) Mass Rape: The War against Women in Bosnia-Herzegovina, pp. 197-218. University of Nebraska Press. Lincoln and London.

- Denich, Bette (1995): 'Of Arms, Men, and Ethnic War in (Former) Yugoslavia', in Constance R. Sutton (ed.) Feminism, Nationalism and Militarism, pp. 61-71. Association for Feminist Anthropology/American Anthropological Association. USA.

- Elshtain, Jean Bethke (1981): Public Man, Private Woman: Women in Social and Political Thought. Princeton, Princeton University Press. New Jersey.

- (1987): Women and War. The University of Chicago Press. Chicago.

- Folnegovic-Smalc, Vera (1994): 'Psychiatric Aspects of the Rapes in the War against the Republics of Croatia and Bosnia-Herzegovina', in Alexandra Stiglmayer (ed.) Mass Rape: The War against Women in Bosnia-Herzegovina, pp. 174-179. University of Nebraska Press. Lincoln and London. . Grant, Rebecca (1992): 'The Quagmire of Gen- der and International Security', in V. Spike Peterson (ed.) Gendered States: Feminist (Re)Visions of International Relations Theory, pp. 83-97. Lynne Rienner, Boulder.

- Hansen, Lene (2000a): 'Past as Preface: Civilizational Politics and the 'Third' Balkan War', Journal of Peace Research 37 (3): 345-362.

- (2000b): 'The Little Mermaid's Silent Security Dilemma and the Absence of Gender in the Copenhagen School', Millennium 29 (2).

- Kennan, George (1993): 'Introduction - The Balkan Crises: 1913 and 1993', in Carnegie Endowment for International Peace. The Other Balkan Wars: A 1913 Carnegie Endowment Inquiry in Retrospect with a New Introduction and Reflections on the Present Conflict by George F. Kennan, pp. 3-16. Carnegie Endowment, Washington, DC.

- Krause, Keith and Michael C. Williams (1996): 'Broadening the Agenda of Security Studies? Politics and Method' Mershon International Studies Review 40 (2): 229-54.

- MacKinnon, Catharine A (1989): Toward a Feminist Theory of the State. University Press, Cambridge, Massachusetts: Harvard.

- (1994): 'Rape, Genocide, and Women's Human Rights', in Alexandra Stiglmayer (ed.) Mass Rape: The War against Women in Bosnia-Herzegovina, pp. 183-196. University of Nebraska Press, Lincoln and London.

- Mestrovic, Stjepan G (1994): The Balkanization of the West: The Confluence of Postmodernism and Postcommunism. Routledge, London.

- Morokvasic, Mirjana (1998): 'The logics of exclusion: Nationalism, sexism and the Yugoslav war', in Nickie Charles and Helen Hintjens (eds.) Gender, Ethnicity and Political Ideologies, pp. 6590. Routledge, London.

- Nikolic-Ristanovic, Vesna (1996): 'War and Violence Against Women', in Jennifer Turpin and Lois Ann Lorentzen (eds.) The Gendered New World Order: Militarism, Development, and the Environment, pp. 195-210. Routledge, London.

- Ramet, Sabrina Petra (1996): Balkan Babel: The Disintegration of Yugoslavia from the Death of Tito to Ethnic War. Boulder: Westview. 2. edition.

- Rodgers. Jane (1998): 'Bosnia, Gender and the Ethics of Intervention in Civil Wars', Civil Wars 1 (1): 103-116.

- Seifert, Ruth (1994): 'War and Rape: A Preliminary Analysis', in Alexandra Stiglmayer (ed.) Mass Rape: The War against Women in Bosnia-Herzegovina, pp. 54-72. University of Nebraska Press, Lincoln and London.

- Stanley, Penny (1999): 'Reporting of Mass Rape 
in the Balkans: Plus ca change, plus c'est même chose? From Bosnia to Kosovo', Civil Wars 2 (2): 74-110.

- Stiglmayer, Alexandra (1994): 'The Rapes in Bosnia-Herzegovina', in Alexandra Stiglmayer (ed.) Mass Rape: The War against Women in Bosnia-Herzegovina, pp. 82-169. University of Nebraska Press, Lincoln and London.

- Steans. Jill (1998): Gender and International Relations: An Introduction. Polity Press, Cambridge. - Tickner, J. Ann (1992): Gender in International Relations: Feminist Perspectives on Achieving Global Security. Columbia University Press, New York.

- Todorova, Maria (1997): Imagining the Balkans. Oxford University Press, Oxford.

. Walker, R. B. J. (1992): 'Gender and Critique in the Theory of International Relations', in V. Spike Peterson (ed) Gendered States, pp. 179-202.

Lynne Rienner, Boulder.

- Zarkov, Dubravka (1995): 'Gender, Orientalism and the History of Ethnic Hatred in the Former Yugoslavia', in Helma Lutz, Ann Phoenix and Nira Yuval-Davis (eds.) Crossfires: Nationalism, Racism and Gender in Europe, pp. 105-120. Pluto Press, London.
Summary

The mass rapes in Bosnia brought gendered problems of security onto the international agenda to an unprecedented extent. This article examines the debate whether these rapes should be characterised as a problem of security, which warranted international attention and possibly intervention. The debate evolved around the question whether wartime rape should be understood as an individual risk or a collective security problem; and whether it should be defined in national or gendered terms. The article analyses three dominant representations of the Bosnian mass rapes: "rape as normal/Balkan warfare", "rape as exceptional/Serbian warfare", and "Balkan patriarchy" and their different interpretations of the mass rapes.

Lene Hansen, ph.d., lektor Institut for Statskundskab, Københavns Universitet 